\title{
SPATIAL AND ARCHITECTURAL DESIGN ASPECTS IN COMMUNITY BASED MOSQUES
}

\author{
Luluk Maslucha
}

\author{
Department of Architecture, Faculty of Science and \\ Technology \\ Universitas Islam Negeri (UIN) Maulana Malik Ibrahim \\ Malang \\ J. Gajayana 50 Malang, Jawa Timur, Indonesia \\ Phone/Fax. : +62 341558933 \\ e-mail: Ilk_maslucha07@yahoo.com
}

\begin{abstract}
Indonesia as one of the biggest Muslim countries in the world are very rich in the quality and quantity of mosques architecture. The largest number of mosques in Indonesia is designed, built, and developed by local communities. Unfortunately, the potention of these kind of mosques is often unconsciously forgotten in the field of architectural studies. Therefore, this research is held to define these mosques' spatial and architectural design aspects which were considered as appropriate for the needs of their local communities'. As a descriptive-qualitative architectural research, the methods employed in this research are (1) field surveying, (2) architectural documenting, and (3) informal interview, which were held in three purposive sample of mosques: Masjid An-Nur Jagalan, Masjid Gading Pesantren, and Masjid Jami' Kauman Malang. These three mosques were chosen because of their close relations with their surrounding communities and their long time developments by their local societies. The result of this study shows that some specific spatial and architectural elements which were found in these community based mosques are (1) the scale, size, and depth of space, (2) the classification and the placement of space, (3) the architectural expressions, (4) the openness, the boundaries, and the relationship between spaces, (5) the athmospherical qualities of space, (6) the classification of the users in spaces, (7) the intensity of the users in spaces, and (8) the manner and the position of the users in spaces.
\end{abstract}

Keywords: spatial and architectural aspects, community based mosque

\begin{abstract}
Abstrak
Indonesia merupakan salah satu negara muslim terbesar di dunia sangat kaya akan kualitas dan kuantitas arsitektur masjid. Jumlah masjid terbesar di Indonesia didesain, dibangun, dan didirikan oleh komunitas lokal. Sayangnya, potensi dari masjid-masjid ini seringkali secara tidak sadar dilupakan pada ranah studi arsitektur. Karena itulah penelitian ini dilakukan untuk mendefinisikan aspek desain ruang dan arsitektural masjid-masjid ini yang dipertimbangkan sesuai dengan kebutuhan masyarakat lokal. Sebagai penelitian arsitektural kualitatif deskriptif, metode yang digunakan pada penelitian ini antara lain (1) Survei lapangan, (2) dokumentasi arsitektural, dan (3) wawancara informal, yang dilakukan pada tiga sampel masjid: Masjid An-Nur Jagalan, Masjid Gading Pesantren, dan Masjid Jami' Kauman Malang. Ketiga masjid ini dipilih karena kedekatan mereka dengan masyarakat sekitar dan pembangunan yang lama oleh masyarakat lokal. Hasil dari studi ini menunjukkan bahwa beberapa ruang dan elemen arsitektural tertentu ditemukan pada tiga masjid berdasar komunitas ini, antara lain (1) skala, ukuran, dan kedalaman ruang, (2) klasifikasi dan penempatan ruang, (3) ekspresi arsitektur, (4) keterbukaan, pembatas, dan hubungan antar ruang, (5) atmosfer kualitas ruang, (6) klasifikasi pengguna dalam ruang, (7) intensitas penggunan dalam ruang, dan (8) tingkah laku dan posisi penggunan dalam ruang.
\end{abstract}

Kata kunci: aspek ruang dan arsitektural, masjid berdasar komunitas

\section{Introduction}

Indonesia as one of the biggest muslim countries in the world are very rich in the quality and quantity of mosques architecture. This is caused Islam spread in almost all parts of Indonesia with different ethnic traditions and customs. This is why the mosque architecture in Indonesia is very diverse, appropriate with local conditions of the local community. Mostly mosques in Indonesia is designed, built, and developed by the local communities. Over 
the last decades, growth of mosques in Indonesia showed a significant increase of. Although lower than the growth of other religious houses of worship, in the period 1997 to 2004 the growth rate of the mosque in Indonesia reached $64 \%{ }^{1}$. This phenomennon was encouraging, since the development of mosques in indonesia both by individual, government, as well as local communities, indicate the concern of communities's needs of adequate mosques for moslem's worship. Unfortunately, the potention of these kind of mosques is unconsciously often forgotten in the field of architectural studies.

In recent years can be found several mosques designs that show uniformity of architectural style which is influenced by several things, one of which is due to a shift in development objectives of this mosque. Especially the monumental mosques built by the government or individuals. In recent years, local governments in various regions in Indonesia seem to build monumental mosque with the high cost. The aim is to enhance the prestige of their region. Because the pomp and luxury, monumental mosques were later shifted its function to be a $f$ ziarah tourism ${ }^{2}$. These mosque's architectural designs are no longer showing the identity of the communities and the blending with the local communities. The impression's of these mosques showing an arogancy, monumentality and distance of the surrounding communities.

The impact of the presence of mosques with a monumental architectural design is not always good for the local community. Local communities are often the last people to be considered in the architectural design of this monumental mosques. The design of monumental mosques often causing mudharat and psychological distance between the mosque and the communities, because the mosque was attended with their prominence but they was so alienated from the surrounding environment ${ }^{3}$.

This is very different from the self funded mosques that are built by the communities. In these mosques, have a close relationship and much of sense of belonging of their communities. Local wisdom and deep understanding of the local communities characteristics was also manifested in the mosques architectural design that they built.

In this paper will be raised how the uniqueness of the spatial and architectural design aspects at 3 mosques in the few areas in Malang, East Java. It is based on aspects of distinctiveness of the famous Islamic communities in Malang, Masjid Jami Kauman, Masjid Annur Jagalan, and Masjid Gading.

\section{Methods}

As a descriptive-qualitative architectural research, the methods employed in this research are (1) field surveying, (2) architectural documenting, and (3) informal interviews, the which were the resource persons held in three purposive sample of Mosques: Masjid An-Nur Jagalan, Masjid Gading Pesantren, and Masjid Jami 'Kauman Malang. These three were the resource persons chosen mosques because of their close relations with communities and their surrounding and their long time developments by local societies. The result of this study shows, That some specific spatial and architectural elements found in the which were the resource persons these are community-based mosques (1) the scale, size, and depth of space, (2) the classification and the placement of space, (3) the architectural expressions, (4) the openness, the boundaries, and the relationship the between spaces, (5) the athmospherical qualities of space, (6) the classification of the users in spaces, (7) the intensity of the users in spaces, and (8) the manner and the position of the users in spaces.

\section{Discussion}

Discussion of aspects of architectural design and spatial mosque in this study are grouped into three components based on space division components, (1) fixed-feature components, (2) semifixed features components, and (3) non fixed-feature components.

\section{Fixed-Feature Components}

The first space component is a fixed-feature components, (a) the scale, size, and depth of space, (b) the classification and placement of space, and (c) the architectural expressions. Spatial elements and architectural components are grouped into a fixed space (fixed-feature) because these elements tend to be fixed and not changed in the long term.

\section{a. The Scale, size, and depth of space}

There is a difference in scale space in the third mosque studied. There was a monumentality in space scale in the main prayer room of the Masjid An-Nur Jagalan and Masjid Jami' Kauman, while the scale of the main prayer space in Masjid Gading Pesantren mostly familiar. However, in the third mosque there is a proportional ratio between the overall scale of the mosque building with outer space and the scale of the surrounding environment. In Masjid An-Nur Jagalan and Masjid Gading Pesantren scales formed between the mosque building with the surrounding residential neighborhood is a fairly intimate scale space. Meanwhile, the Masjid Jami 'Kauman, monumental scale is formed by the fusion of mosque building in the square that is wide enough in front of the mosque. Psychologically, the monumental scale giving effect a sense of 'small' and 'foreign' to the environment. Space outside the mosque a familiar scale to help visitors who come to feel 'closer' and 'acceptable' in the mosque's neighborhood.

The scale of the mosque with the surrounding environment is part of the human perception of shape (form). This is consistent with the theory proposed in Gestalt Theory ${ }^{4}$, that there are 6 (six) properties that influence the perception of shape (form), 1) proximity, 2) similarity, 3) closure, 4) continuity, 5) area and symmetry, and 6) figure and ground. The scale of the mosque in this case relates to the distance and size, when the mosque was in 
the neighborhood, then the distance which tend to be close to home and communities supported the mosque an inconspicuous appearance, giving the effect of similarity (similarity) with its environment, so it does not seem strange in the neighborhood. When the mosque which has close proximity to the settlements have too monumental scale, it will give effect to contrast with the surrounding environment, and memorable are not familiar.

Therefore, the most appropriate scale of space and buildings for community based mosques is an harmonious scale with the surrounding environment. There are quiet familiar scale of the building and surrounding outer space, balancing size with surrounding environment, and not so monumental. The size and depth of the mosque is closely linked to the scale space. Large spaces tend to have a monumental scale. In the third mosque studied, the size of the main mosque prayer room tends to exceed the space requirements for prayers five times a day on weekdays. This is evident from the mosque daily occupancy during the five daily prayers that only about one to thirteen rows, while the number of rows that are available in mosques it is twenty (Masjid Gading Pesantren), forty (Masjid AnNur Jagalan) to ninety (Masjid Jami 'Kauman) rows. Mosque of daily occupancy at most of the time the five daily prayers can reach up to $50 \%$ of the main prayer space can only be observed in the Masjid Gading Pesantren. The rest, the main prayer halls of mosques are just filled with worshipers at Friday prayers and the prayers in Idul Fitri and Idul Adha. At the times like these, the main mosque prayer room is insufficient for the number of jamaah, so the patio and yard is also used as a prayer area.

Meanwhile, based on the behavioral science in architecture, size and depth of field affect human perception of space. The space is too large and in tended to be perceived as a space alien or gripping. This is due, the human perception of space is influenced by several things, among them by size. The size can also affect the depth of space. Objects closer seem larger than the same size but with a longer distance ${ }^{5}$. It can be observed also in the room. Edward $\mathrm{T}$. White states, a reasonable scale will adjust the space between the size of the room with the activities carried out in it, and is based on the physical and spiritual comfort. The book also explained that there is also a lounge with a magnificent scale, where the size of the existing excess space for the activities in it, this is usually to give the impression of majesty and grandeur. That opinions can provide an overview on this research, that when the mosque is located in the middle of the settlement has a large room sizes and contrasts with the surrounding environment, it will increasingly look great as the distance to the surrounding environment is relatively close. The size of a large space will also give the impression of space with great scale, that would provide 'psychological distance' with the surrounding community.

Thus, the size and depth of the main prayer halls of mosques-based society should be considered in accordance with the needs and daily occupancy mosque, the mosque in order not to be too large and monumental. Furthermore, to meet the needs of occasional mosque during Friday prayers or prayers in Idul Fitri and Idul Adha, patio and courtyard of the mosque as a multipurpose area that can be expanded. Therefore, the design of the terrace and the courtyard of the mosque also should consider the possibilities of expansion of worshipers at this particular moment.

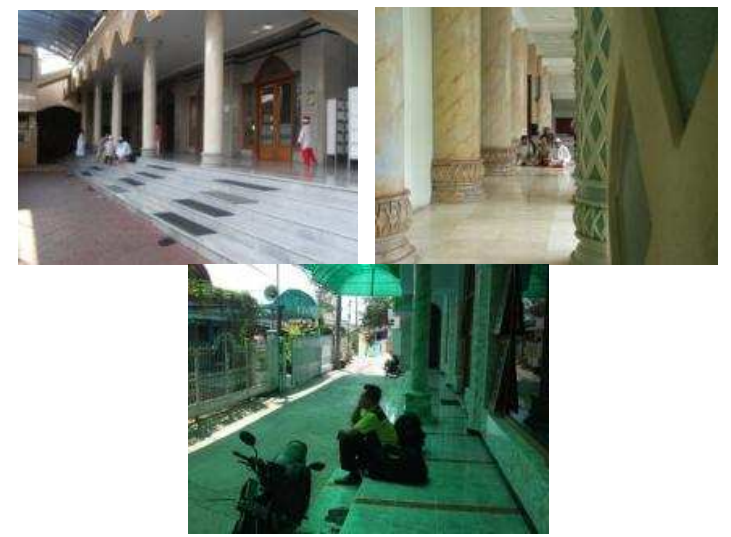

Figure 1. Scale, size, and depth of space in Masjid Annur Jagalan, Masjid Jami’ Kauman, and Masjid Gading Pesantren

\section{b. The classification and placement of space}

In general, according to the classification and positioned space contained in the third mosque studied can be divided into three zones, (1) inner zone, consisting of a prohibited space such as the mihrab and the main prayer room, and specificpurpose space such as ablution space and space for takmir , (2) transition zone, consisting of a multipurpose space like a patio or porch, and (3) outer zones, consisting of yard and path that are outside space. Based on the type and placement spaces on the third of this mosque, it can be observed the peculiarities of behavior of jamaah who come from local people and newcomer jamaah or traveler. As noted earlier, jamaah who came from the local community has a tendency to directly enter the main prayer space, whereas the newcomer jamaah or travelers tend to perform activities on the patio or porch before and after the following prayers in the main prayer room. Based on the theory of territoriality, this trend shows that the jamaah who came from the local community have regarded the mosque as part of their territory (territories secondary). Meanwhile, the newcomer or traveler jamaah consider that they are not their territory. Therefore, their behavior indicates that they feel more comfortable to move in outer space zone or transition zone (public territory). This is interesting, because as a public building or facility mosque is actually 'owned' by all elements of muslim society. But this phenomenon is also very reasonable because a person's behavior in areas unfamiliar to him usually strongly influenced by the initial perception of the region. Conversely, if the region has been frequently visited, the initial perception is no longer the main 
thing that affects behavior. There has been a process of 'habituation' or habituation that makes a person less sensitive again in response to his surroundings. Habituation or habituation occurs when a stimulus that can be perceived no change or constant, so the response to it has decreased. According to Holahan ${ }^{6}$, there are 3 aspects contained in the environmental stimuli, namely (1) contains nothing new, (2) contains a surprise, and (3) reveals inequality. Therefore, if there are senses in humans can not catch a novelty, surprise, or perceived inequality in the environment, then the response that occurs will decrease the intensity. Of behavioral phenomena that occur on the third mosque above, can be seen that the jamaah who come from surrounding communities more use of the main prayer hall, and many newcomer jamaah and travelers using the patio area or transition zone. This suggests that habituation occurred in jamaah from the surrounding community who freely use the main prayer hall. In contrast to immigrants from outside and travelers who consider that the mosque is a place that is new to them, so they do not usually use the main prayer hall which is still foreign to them. The newcomer jamaah tend to choose the transitional zone of the terrace which is a public territory.

Since the jamaah arrivals are still strongly influenced by the initial perception of the environment in the early times of his coming to the mosque, then attention to the impact of the draft zone of outer space and that this transition zone to the perception they need attention. It is important to design the outer space zones and transition zones are open and accepting entrants memorable. Some examples are the design of barrier that is not too close, the terrace is quite spacious, comfortable, and quiet, placement terrace and the main prayer room which is easily visible and accessible from outside the footprint, circulation is easily understood, and the pages are pretty open. Meanwhile, for the jamaah who came from the local community, physical considerations such as ease of achievement, comfort, and peace of the main prayer room is also a factor to consider.

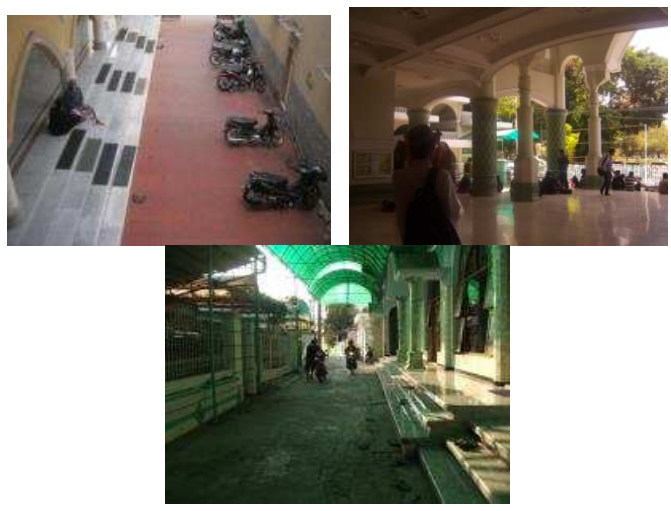

Figure 2. The classification and placement of space in Masjid Annur Jagalan, Masjid Jami' Kauman, and Masjid Gading Pesantren

\section{c. Architectural Expression}

Of the three studied mosque, an architectural expression of Masjid Jami Kauman more grandiose and monumental than two other mosques. This is due to the length of the journey of this mosque and the many who have gone through the process of renovation. In addition, the Masjid Jami 'Kauman also located just west of alun-alun Malang that led to the monumental scale of the building which was proportional to the size of the plaza area. However, when entering the main prayer room, a look of grandeur and monumentalism was quite balanced by the locality of architectural form, structure, and material will be retained since the mosque was first built. Therefore, the architectural expression that can be observed in the main prayer room is the architectural expression that was familiar to the local community for decades.

Meanwhile, two other mosques of architectural expression is more simple and in harmony with the surrounding residential neighborhood. Comparison of the scale of the mosque building with the surrounding buildings are not too flashy, even the existence of mosques tend to blend with the residential buildings around it. Mosque which reaches a height of two floors is also quite balanced with residential buildings which height ranged between one and two floors. Architectural vocabulary that is used is also not much different from the surrounding environment, such as models of doors and windows, flooring and wall material, barrier, open layout and space, and so on.

The third equation of this mosque is the third use the same architectural language that has been conceived as a feature of the mosque communities are commonly used, among which is the number of doors and windows to be a marker of openness mosque, a minaret or roof forms that become markers of the mosque, the calligraphy on the walls, and so on. The existence of such markers is very important that the mosque can be identified or recognized as a mosque by the community, both local people and travelers or immigrants. As already known, the community has a collective memory of the forms which for years they identify and record as the prevalence of the mosque. Hershberger ${ }^{7}$ in his writings, "predicting the Meaning of Architecture", stating that the meaning of such a process is categorized into the referential meanings associated with the introduction of the form as a symbol of an object or other events, an introduction to the use and benefit (physical, physiological, psychological, social, cultural, and so on).

However, it does not mean an architect is bound only to the referential meanings held by this society. The design of the mosque-based architectural expression of this referential meaning, as stated by Mohd. Tajuddin, can be restricted only to the extent that the building had been known as a mosque by the community. Moreover, the architects can explore the diverse architectural forms as long as it does not contain the harm (mudharat). 


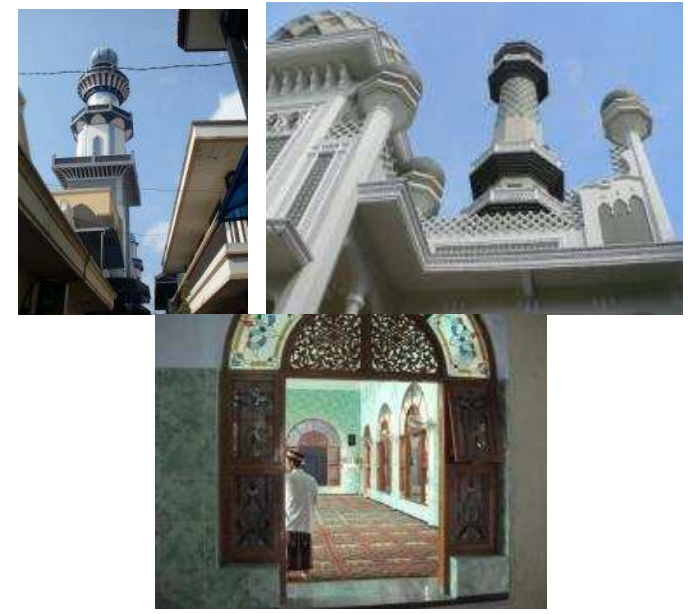

Figure 3. The Architectural Expression of Masjid Annur Jagalan, Masjid Jami Kauman, and Masjid Gading Pesantren

\section{Semi-fixed Feature Components}

The second group is semi fixed feature component, (a) the openess, the boundaries, and the relationship between space, and (b) the asphomerical qualities of space. This spatial and architectural elements are grouped into a semi fixed feature because these elements tend to be somewhat fixed but can change fairly, quickly, and easily.

a. The Openness, the boundaries, and the relationship between space

Of the various spaces contained in the third mosque studied, in general the main rooms such as the mihrab, the main prayer room, terrace, and yard are open spaces. Mihrab spaces together with the main prayer room, but still can be distinguished from the size of the main prayer room. The main prayer halls in the third mosque was entirely furnished with lots of doors and windows which produces an open impression. Due to the presence of doors and windows that can be easily opened and closed here, the degree of openness of the main prayer room to be very flexible and can be changed at any time depending on the activity that takes place in it. However, the presence of the walls still produce a strong impression of space and a separate area with a terrace and courtyard. The relationship between the main prayer room with terrace was still a juxtaposition relationships, because they still specifically limits the space between them.

From the standpoint of perception of space, it is important to still be able to distinguish the types of existing space in the mosque, according to the benefits of each, that is prohibited space, multipurpose space, specific purpose space, and outside space. Sometimes, these spaces are required to be open, but still recognizable the differences. Prohibited space such as the mihrab and the main prayer space bound by the rules of prayers, while the patio or porch is more multipurpose so it can be designed more flexible. Some spaces such as women's prayer rooms that are semi-permanent, ablution rooms, and bathrooms have more limited openness due to demands for privacy in these spaces.

From the above considerations, the design of the main mosque spaces can be designed in a flexible openness through the use of limiting elements of a semi fixed. Nevertheless, the distinction of each room should still be recognized through the juxtaposition relationship between space. Interpenetration spaces can also resulted any time, for example during Friday prayer or more events that requires more open space. This can resulted with barrier elements which flexible and semi fixed, such as folding doors, walls shear, and so on. However, the interpenetration spaces are can not be designed as fixed or permanent spaces because of the need for a clear distinction in the activities of worship in the main prayer room and more diverse activities in the terrace of the mosque.

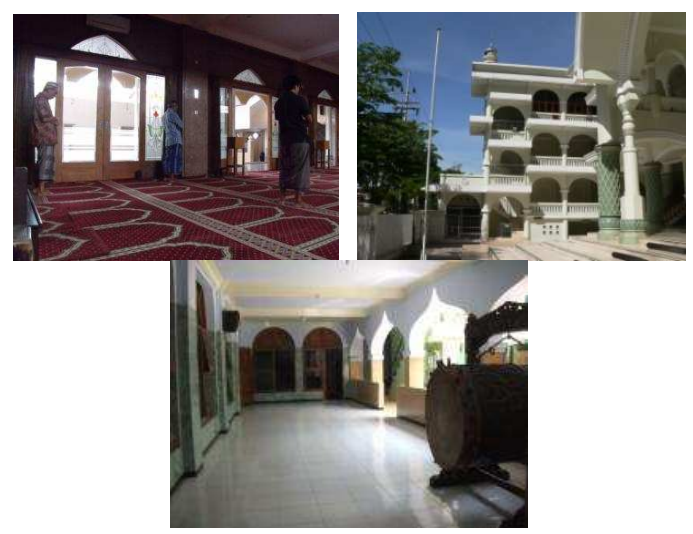

Figure 4. the openess, the boundaries and the relation between space in Masjid Annur Jagalan, Masjid Jami' Kauman and Masjid Gading Pesantren

\section{b. The atmospherical qualities of space}

Of some aspects of atmospherichal space that can be felt, lighting is one aspect that greatly affects human perception. Natural lighting and artificial lighting in the third mosque studied producing quality space suitable atmosphere for worship activities and educational activities that take place in it. The atmospherical inner space zone in the mosque is quite bright but not dazzling because it is not from direct sunlight, but the diffuse light entering through existing openings. Similarly, the quality of air circulation and acoustics in the main prayer room. Cross ventilation derived from the number of open doors and windows make the rooms are quite comfortable. The existence of elements of semi-permanent barrier to absorb sound and also prayer rugs to help create peace in the main prayer room.

In the other hand, the quality of the atmosphere in the room terraces of the mosque is actually less attention. In some areas of the terrace, natural lighting obtained is the direct rays of the sun's glare and heat. This is because the ceiling height is too 
monumental terrace to shade from the sun, wind, and rain. Location of terraces that are too close to the road also resulted in this area is easy to obtain the flow noise and dust coming from the road. This is unfortunate because it is actually the terrace is the best place chosen by the travelers, as described in the previous section. In addition, the terrace is also a multi purpose room which is very useful for a variety of activities at the mosque. Therefore, the atmospherical quality aspects of space, and the design of comfortable teracce must be considered, although not the same with the atmospherical quality in main prayers space. Thus, not only the perception of the early travelers jamaah will be formed by the comfortable of the terrace of this mosque. A long with the existencies of mosques with local communities, referential meanings can be formed by use the terrace for a variety of social activities at the mosque daily.

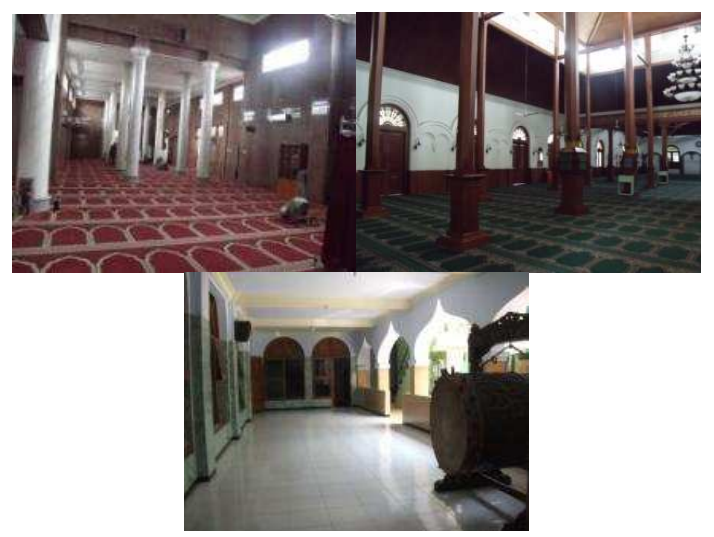

Figure 5. the asmopherical qualities of space in Masjid Annur Jagalan, Masjid Jami' Kauman and Masjid Gading Pesantren

\section{Not-fixed Feature Components}

The third group of the space component is non fixed feature, (a) the classification of the users in spaces, (b) the intensity of the user space, and (c) the manner and position of the user space. This elements are grouped into non-fixed feature component because these relation with humans and their setting that can always change every time.

\section{a. The classification of the users in spaces}

As described in the previous chapter, there are two main groups of users mosque which has a different behavior pattern, jamaah who came from the local community and travelers or jamaah who are coming from different areas. In the three mosques that have been studied, there are differences in the ratio between the number of local jamaah and newcomers jamaah. In Masjid An-Nur Jagalan, the number of local jamah and travelers jamaah can be quite balanced in times of ta'lim. Outside these times, jamaah is dominated by the local communities. Meanwhile, there bit of travelers jamaah in Masjid Gading Pesantren. Local jamaah is dominated by students. Travelers jamaah mostly as non-local student that regulary come to masjid for pray or ta'lim.

In contrast, in the Masjid Jami' Kauman, the intensity of travelers jamaah who come to the mosque are not regular enough, especially in the afternoon until the evening. In addition to the above grouping, behavior patterns of jamaah can be classification based on age. Old people, adults, adolescents, and children encountered as user groups in mosque. Children tend to use the mosque as a place to play, meet friends, and study. Sometimes children are not following prayers, but keep playing while waiting to be study on the terrace and courtyard. Meanwhile, the other age groups use mosques as a place of worship in addition to the five daily prayers in congregation as well as a place to stay in touch with neighbors and friends.

From the above it can be observed that the presence of various groups who use the mosque for a variety of activities led to the design of the mosque should consider the existence of these various circles. Children who like to play in the mosque should also be considered its existence. Consideration of the existence of children in the mosque can not be avoided, because this is where they get religious education are sometimes not available to them at school and at home. Children can not be kept away from the mosque, because of their referential meaning when adults are also began from childhood. The design of the mosque can be more friendly to children, taking into account the factor of safety and comfort them, while still considering play as the usual activity on the terrace and in the yard does not disturb the worship activity in the main prayer room. For that, the existence of terraces and yard as a multi-purpose area must get the good consideration of various aspects.

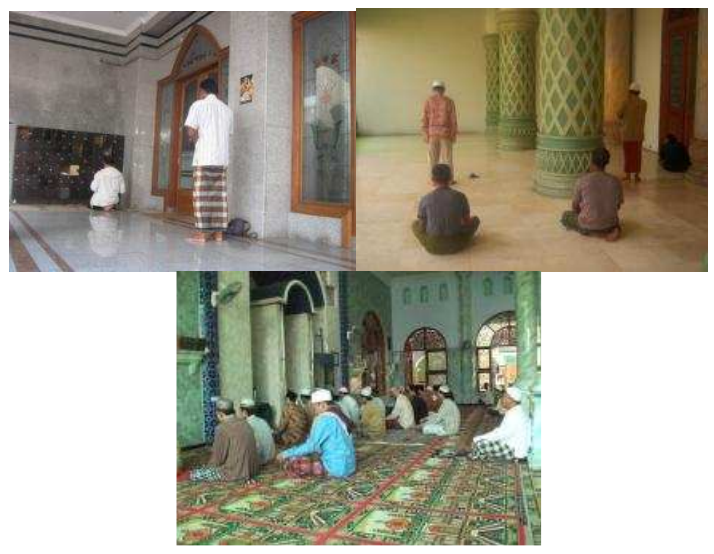

Figure 6. the users in spaces in Masjid Annur Jagalan, Masjid Jami' Kauman and Masjid Gading Pesantren

\section{b. The intensity of the users in spaces}

The intensity of the third user of this mosque is very high at certain moments, such as, prayers, learning the Koran, haul, and Friday prayers. However, the daily occupancy at the mosque during prayer five times a day is only about one to thirteen 
rows, while the number of rows that are available in mosques it is twenty (Masjid Gading Pesantren), forty (Masjid An-Nur Jagalan) up to ninety (Masjid Jami 'Kauman) rows. The daily occupancy at most of the time the five daily prayers can reach up to $50 \%$ of the main prayer space is only found in Masjid Gading Pesantren.

Above facts show that basically the mosque is a multifunctional institution, religious and social functions. Therefore, consideration of the ratio of main prayer room as a prohibited space with wide terraces and a yard that multipurpose should based multi-functionality of this community. The calculation may take into consideration the vast space occupancy prohibited mosque for daily prayers five times, while the vast multipurpose space calculation may consider high intensity users on the occasional mosque activities as mentioned above.

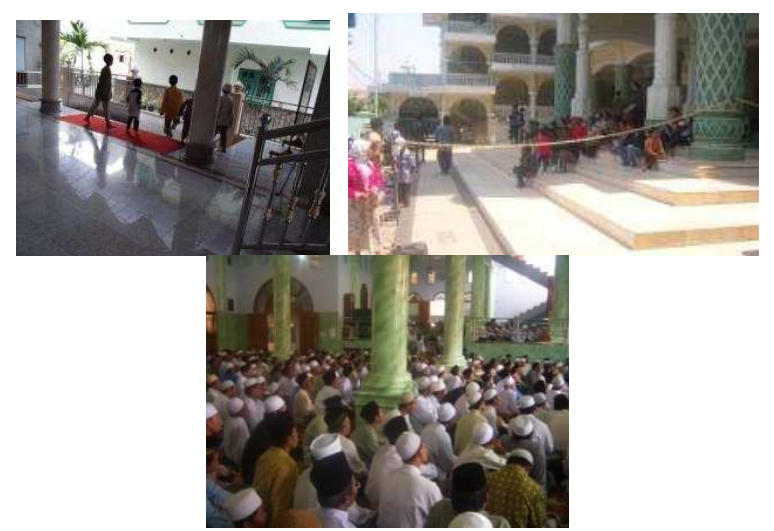

Figure 7. the intensity of users in spaces in Masjid Annur Jagalan, Masjid Jami' Kauman and Masjid Gading Pesantren

\section{c. The Manner and the Position of the Users in Space}

The similarity of the manner and the position of the users can be observed from the third jamaah mosques are came from the local communities that has a tendency to directly enter the main prayer space and move in it, whereas the travelers jamaah tend to move in the terrace mosque a more open and within easy reach. This can be seen from the user's position in the Masjid Jami 'Kauman a much visited by travelers. The intensity of activity in the area of the front terrace and side of the mosque is quite high, especially at times when quite a lot of travelers who visit at this mosque. The travelers rested, calling, chatting, lying down, prayed circumcision in the terrace area of the mosque. Some jamaah travelers even have a tendency to connect the first row in the prayers in this terrace area, instead of taking place in the back row in the main prayer room. Conversely, the local community of Kampung Kauman most directly to the main prayer room and perform various activities in it. By contrast, in the Masjid Gading Pesantren rarely visited by travelers enough, the intensity of activity in the terrace area is very low. Only when there are one or two travelers who stop at this mosque, they make use of the terrace as a place to wait for the implementation of the prayer. Most of the jamaah who are local students or non local students prefer to directly enter the main prayer room area. Another phenomenon related to the behavior typical of this jamaah is the choice of location when praying. In the third mosque studied, the general location of jamaah who occupy the first rows are the old people and adults.

\section{Conclusions}

1. The calculation may take into consideration the vast space occupancy prohibited mosque for daily prayers five times, while the vast multipurpose space calculation may consider high intensity users on the occasional mosque activities as mentioned above. Thus, all functions can be embodied in the mosque as well without making the mosque building needs grow beyond the limit, and to avoid the monumentality and disproportionate to the scale of buildings in the surrounding environment

2. It is important to design the outer space zone and transition zone that memorable journey, or open and receptive to newcomers, this is because the travelers are just one or two visits to the mosque is still heavily influenced by their initial perceptions of the design of the mosque. Some examples are the design of barrier that is not too close, wide terrace,, comfortable, placement terrace and the main prayer room which is easily visible and accessible from outside, easy circulation, and the open yard.

3. The design of the mosque should utilize markers that have been known in the community, so the building can be identified as a mosque by the community, both local people and travelers. The design of the mosque-based architectural expression of this referential meaning can be restricted only to the extent that the building had been known as a mosque by the community. Moreover, the architects can explore the diverse architectural forms as long as it does not contain the harm (mudharat).

4. It is important to still be able to distinguish the types of existing space in the mosque, according to the benefits of each, that is prohibited space, multipurpose space, specific purpose space, and outside space.

5. In the aspect of quality of atmospheric space, terrace design is quite comfortable.

6. The existence of various groups who use the mosque for a variety of activities led to the design of the mosque should consider the presence of them all. The design of the mosque can be more friendly to children, taking into account the factor of safety and comfort them, while still considering to play the usual activity on the terrace and in the yard does not interfere with the activity of worship is 
performed in the main prayer room. Therefore, the existence of terraces and yard as a multipurpose area must get the good consideration of various aspects.

7. The design of the spaces at the mosque may consider preferability (the tendency to choose) users for specific locations in the mosque to gain benefits at the same time to avoid harm from the design of these spaces.

\section{Referensi}

1 Suryadarma Ali. 2011. Pertumbuhan Masjid Paling Kecil Dibanding Rumah Ibadah Lain. http: //www.suara-

islam.com/news/berita/nasional/2578pertumbuhan-masjid-paling-kecil-dibandingrumah-ibadah-lain, diakses tanggal 25 April 2011

2 Yulia Eka Putrie. 2010. "Merenungkan Kembali Makna Monumentalitas Arsitektur Masjid". Dalam Prosiding Seminar Makna 101010 Jurusan Arsitektur ITS Surabaya.

3 Yulia Eka Putrie Putrie. 2010. “Merenungkan Kembali Makna Monumentalitas Arsitektur Masjid". Dalam Prosiding Seminar Makna 101010 Jurusan Arsitektur ITS Surabaya.

4 Deddy Halim. 2005. Psikologi Arsitektur: Pengantar Kajian Lintas Disiplin. Jakarta: PT. Gramedia

5 Deddy Halim. 2005. Psikologi Arsitektur: Pengantar Kajian Lintas Disiplin. Jakarta: PT. Gramedia

6 CJ. Holahan. 1976. "Environmental Change in psychiatric setting: A social system analysis". Human Relations. February 1976 vol. 29 no. 2 p. $153-166$

7 Robert G. Hershberger. 1974. "Predicting the Meaning of Architecture". dalam Jon Lang, Charles Burnette, Walter Moleski and David Vachon (eds.). Designing for Human Behavior. Stoudsburg, Pennsylvania: Dowden, Hutchinson \& Ross, Inc. 150 